\title{
Biodiversity and conservation of the Cerrado: recent advances and old challenges
}

\author{
Guarino R. Colli ${ }^{1}$ (D) Cecília R. Vieira ${ }^{2}$ (D) José Carmine Dianese ${ }^{3}$ (D)
}

Published online: 14 March 2020

(c) Springer Nature B.V. 2020

\section{Background}

Covering about 2 Mio. $\mathrm{km}^{2}$ by the arrival of the first European settlers, the Cerrado savannas are second in extent only to Amazonian forests amongst the South American biomes (Diniz et al. 2010; Eiten 1972; Oliveira and Marquis 2002). The Cerrado sits strategically at the centre of the continent, connecting two open vegetation biomes-the Chaco to the southwest and the Caatinga to the northeast - thus forming a diagonal corridor of dry habitats in South America, and simultaneously establishing a biogeographical barrier between two forest biomes-Amazonia to the northwest and the Atlantic Forest to the southeast (Schmidt and Inger 1951; Vanzolini 1963; Werneck 2011). Moreover, it also occurs as isolated patches within other biomes, presumably relicts of a more extensive past distribution (Barbosa et al. 2007; Carneiro Filho 1993; Cole 1960; Pennington et al. 2000). The relief consists of ancient, extensive plateaus dissected by younger valleys, carved by some of the major drainages of South America, i.e., Paraná-Paraguay, Tocantins-Araguaia, São Francisco and Parnaíba (Albert and Reis 2011; Braun 1970; King 1956; Mittermeier et al. 2000). The climate is of the Aw type in Köppen's classification, distinguished by marked and highly predictable seasonality, dry winters, and annual precipitation ranging from 1300 to $2300 \mathrm{~mm}$ (Alvares et al. 2013; Nimer 1989). Soils are old, acidic, nutrient-poor, with high levels of $\mathrm{Al}$ and $\mathrm{Fe}$, and strongly influenced by the water regime (Lopes and Cox 1977; Motta et al. 2002; Vendrame et al. 2013). A complex topography and a dynamic geological history created the highly heterogeneous Cerrado landscape (Furley 1999; Sano

Communicated by David Hawksworth.

Guarino R. Colli

grcolli@icloud.com

Cecília R. Vieira

ceciliavieira@icloud.com

José Carmine Dianese

jcarmine@unb.br

1 Departamento de Zoologia, Universidade de Brasília, Brasília, DF 70910-900, Brazil

2 Department of Biology, Utah State University, 5305 Old Main Hill, BNR 240, Logan, UT 84322, USA

3 Departamento de Fitopatologia, Universidade de Brasília, Brasília, DF 70910-900, Brazil 
et al. 2019), with a pronounced horizontal compartmentalization of the biota into three major habitat types - grasslands, savannas, and forests-determined by local topography, soils and water availability (Colli et al. 2002; Furley 1999; Nogueira et al. 2005; OliveiraFilho and Ratter 2002; Ribeiro and Walter 1998). As in other tropical savannas, fires are frequent and most species have adaptations for survival under a regime of periodic burns (Costa et al. 2013; Frost 1985; Hoffmann 2002; Miranda et al. 2009; Mistry 1998; SalgadoLabouriau and Ferraz-Vicentini 1994). The origins of the Cerrado biota date from the Late Cretaceous, presumably evolving from pre-savanna ecosystems between 145 and 65 mya (Aguiar et al. 2020; Colli 2005; Ratter et al. 1997; Romero 1993), although the current biotic configuration has been established much more recently (Simon et al. 2009).

The Cerrado exhibits intricate biogeographic patterns, shaped by local environments and regional constraints, such as proximity to, or isolation from, neighboring domains and areas with contiguous relief (Werneck 2011). Its biodiversity remains poorly understood and every year many new species are described, indicating that significant biodiversity remains to be discovered (Colli et al. 2016; Diniz et al. 2010; Diniz-Filho et al. 2005). The Cerrado is the most diverse tropical savanna in the world and, except for a few tropical forest regions, has the richest vascular plant flora on the planet (Eiten 1994). Due to the rapid expansion of agriculture and livestock, as well as intensive local forest harvesting, ca. 137 animal species of the Cerrado are endangered (Fundação Biodiversitas 2003; IUCN 2013). However, a lack of basic biological knowledge prevents proper evaluation of the degree of threat for most Cerrado species. About $40-55 \%$ of the Cerrado has already been converted to croplands, pastures, and planted forests (Machado et al. 2004; Mantovani and Pereira 1998; Sano et al. 2010). Nevertheless, conversion of the Cerrado into Brazil's largest farm has received much less attention than deforestation of Amazonian and Atlantic Forests (Marris 2005; Ratter et al. 1997). With less than 50\% of the natural vegetation cover remaining, cleared areas in the Cerrado surpass those in Amazonia (Beuchle et al. 2015; Espírito-Santo et al. 2016; Grecchi et al. 2014). Protected areas represent only $8.3 \%$ of the biome and this percentage drops to $6.5 \%$ when considering only the fraction covered by native vegetation (Françoso et al. 2015). Besides, climate models that incorporate changes in land use and degradation of Cerrado habitats indicate that significant changes may occur in water and carbon cycles, with profound impacts on regional climate and downstream ecosystem services dependent on water (Hoffmann 2002; Hoffmann and Jackson 2000). Therefore, many studies forecast daunting scenarios for the biome (Machado et al. 2004; Rambaldi and Oliveira 2003; Santos and Câmara 2002; Strassburg et al. 2017). As home to many endemic species and at the same time highly threatened by agricultural expansion, the Cerrado is regarded as a global biodiversity hotspot (Mittermeier et al. 2000; Myers 2003; Myers et al. 2000). Managing potential uses of Cerrado biodiversity and natural resources is thus essential to reconcile economic growth and poverty reduction with environmental protection.

Although traditionally focused on Amazonian and Atlantic forests, studies on Neotropical biodiversity and conservation have recently turned to open biomes, especially the Cerrado. For instance, a search performed on 7 March 2020 in the Web of Science (All Databases), using “Cerrado AND (conservation OR *diversity)", returned 4297 articles published between 1948 and 2019. The article publication rate changed little until the late 1990s, but rose sharply in the twenty-first century (Fig. 1). The bulk (93.5\%) of published articles is associated with Brazilian institutions, followed by ones in the USA and the UK, featuring still incipient but meaningful academic collaborations (Fig. 2). Moreover, most articles are associated with institutions in Distrito Federal, São Paulo, Goiás, Minas Gerais, Mato Grosso do Sul, and Mato Grosso (Fig. 3), stressing the importance of adequate 


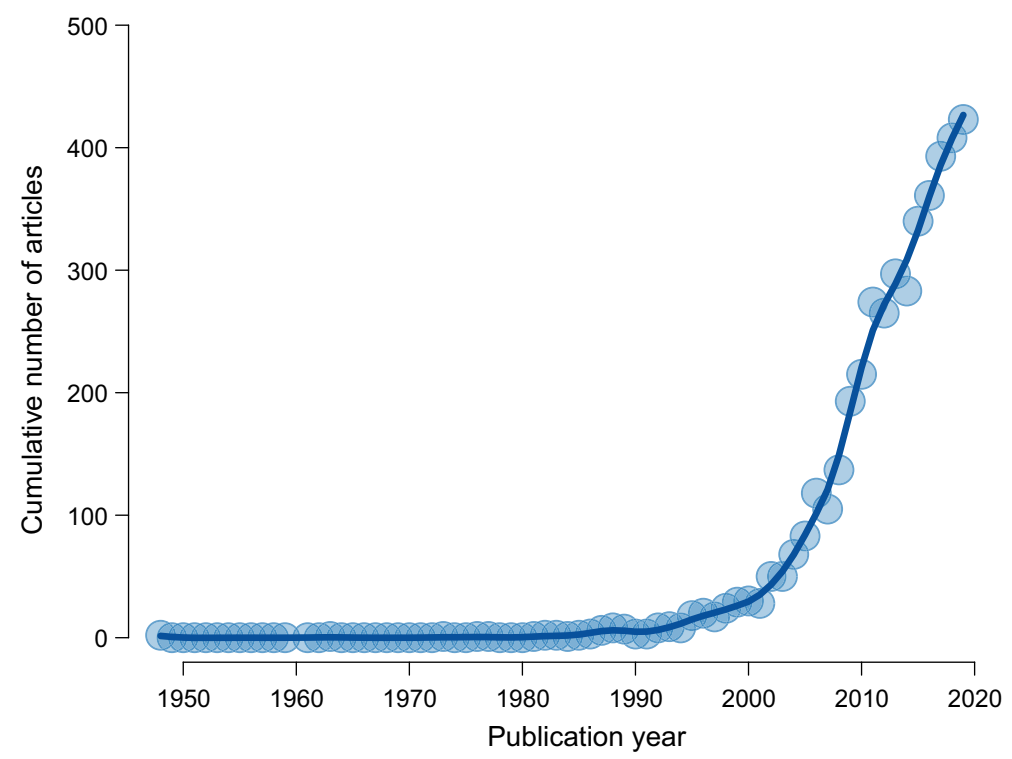

Fig. 1 Cumulative number of articles on Cerrado biodiversity and conservation retrieved from the Web of Science (All Databases) on 7 March 2020, using the expression "Cerrado AND (conservation OR *diversity)". The solid line represents a cubic smoothing spline (Green and Silverman 1994) fitted to the data

funding for research groups and graduate programs, especially those in less privileged regions of central Brazil (Bortolozzi and Gremski 2004; Borges 2008). In this Special Issue, 13 articles present recent advances and major challenges related to biodiversity and conservation of the Cerrado. They reflect not only a great deal of knowledge produced mainly during the last two decades but also the persistence of some old challenges, such as the meager coverage of protected areas in the Cerrado and the paucity of studies involving invertebrates, fungi, and microorganisms. We hope this Special Issue will increase awareness of the importance of this biome, and stimulate future work to overcome these limitations so that scientific knowledge of the Cerrado can help society make informed decisions affecting its' biodiversity and conservation.

\section{Synopsis}

Any effort to address the biodiversity and conservation of a large region depends on a sound understanding of its boundaries and regionalization. Françoso et al. (2020) used tree species inventories from almost 600 localities to identify biogeographic districts and provide a geographic framework for conservation planning and scientific research prioritization in the Cerrado. They recognize seven biogeographic districts characterized by climatic conditions and tree species composition. By assessing their rate of land conversion and coverage by protected areas, they show that districts in the southern and southwestern Cerrado have endured most land conversion and are the least protected. At the same time, those in the north and northeast are less impacted and better protected, stressing their greater need for conservation and management actions. Marques et al. (2020) conducted 

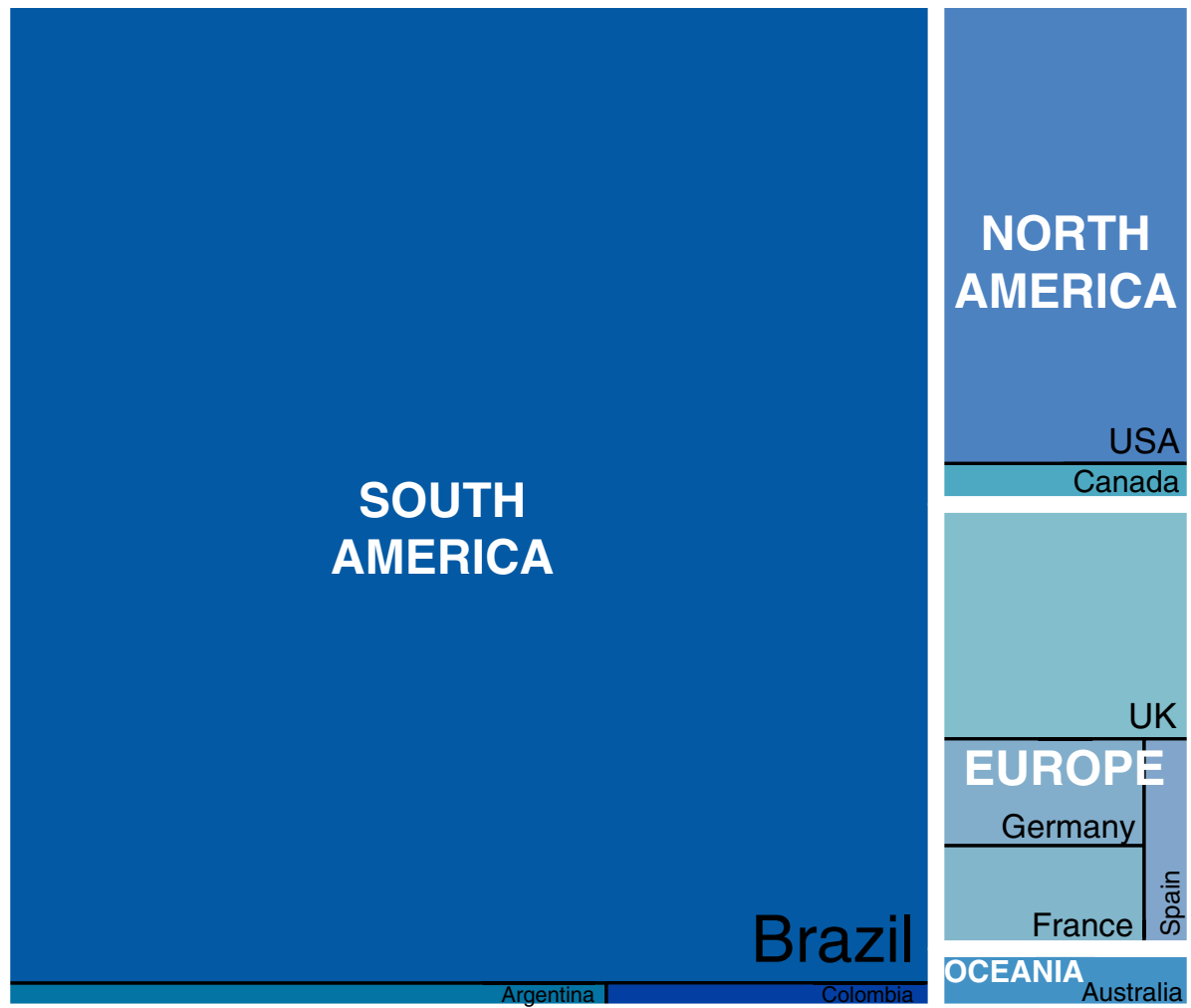

Fig. 2 Treemap depicting the number of articles on Cerrado biodiversity and conservation according to continent and country of authors' institutional affiliation. Articles were retrieved from the Web of Science (All Databases) on 7 March 2020, using the expression "Cerrado AND (conservation OR *diversity)"

a detailed analysis of satellite imagery to assess the spatiotemporally dynamic boundary between the Cerrado and Amazonia. They demonstrate how this boundary is broad, complex, and interdigitating, and that the abrupt line separating the two biomes in official maps is inadequate for biodiversity conservation in the region. Further, they show that the Cerrado-Amazonia transition suffered more deforestation than either the Cerrado savannas or Amazonian forests over the last 30 years, resulting in the loss of ecotonal forests and threatening their unique biota.

The Cerrado is a highly heterogeneous landscape and some of its regions are subject to severe threats and deserve special attention, including the Cerrado-Amazonia transition, which coincides with an "arc of deforestation," and rupestrian grasslands, mainly from the upper parts of the Espinhaço mountain range. Morandi et al. (2020) compared the tree diversity and biomass of typical cerrado vegetation between the Cerrado-Amazonia transition and the central area of the Cerrado. Further, they assessed the effects of temperature and precipitation on biomass and explored the species diversity versus biomass relationship. They found no difference in tree diversity between the two regions. However, they show that typical cerrado vegetation holds more biomass at the periphery than at the centre 


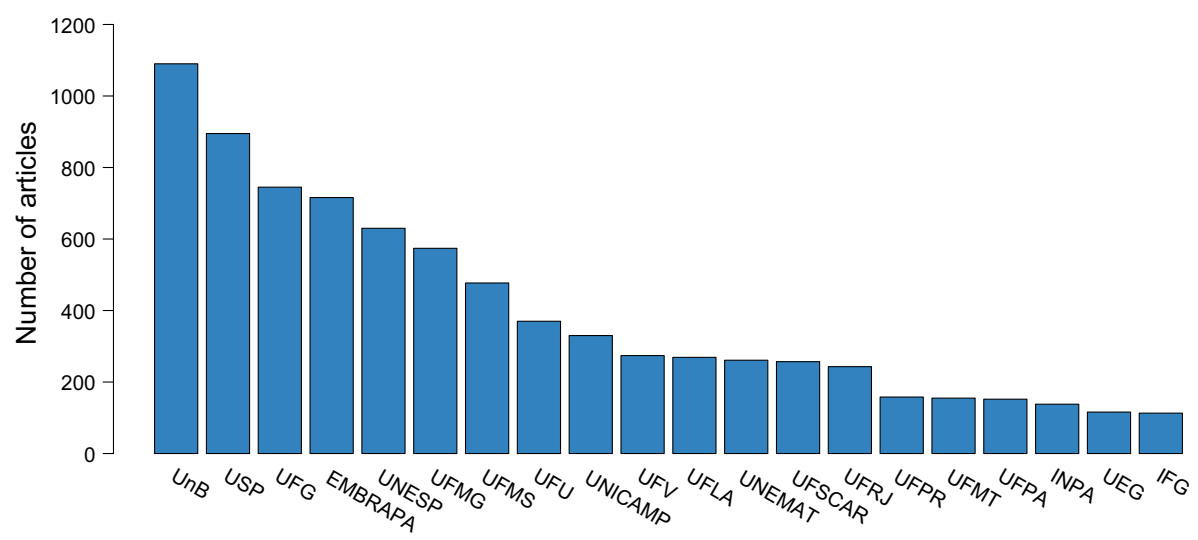

Fig. 3 Histogram depicting the distribution of articles on Cerrado biodiversity and conservation according to authors' institutional affiliation. Articles were retrieved from the Web of Science (All Databases) on 7 March 2020, using the expression "Cerrado AND (conservation OR *diversity)". EMBRAPA: Empresa Brasileira de Pesquisa Agropecuária, IFG: Instituto Federal de Goiás, INPA: Instituto Nacional de Pesquisas da Amazônia, UEG: Universidade Estadual de Goiás, UFG: Universidade Federal de Goiás, UFLA: Universidade Federal de Lavras, UFMG: Universidade Federal de Minas Gerais, UFMS: Universidade Federal de Mato Grosso do Sul, UFMT: Universidade Federal de Mato Grosso, UFPA: Universidade Federal do Pará, UFPR: Universidade Federal do Paraná, UFRJ: Universidade Federal do Rio de Janeiro, UFSCAR: Universidade Federal de São Carlos, UFU: Universidade Federal de Uberlândia, UFV: Universidade Federal de Viçosa, UnB: Universidade de Brasília, UNEMAT: Universidade do Estado de Mato Grosso, UNESP: Universidade Estadual Paulista, UNICAMP: Universidade Estadual de Campinas, USP: Universidade de São Paulo

of the biome, resulting from higher temperatures and more significant precipitation at the periphery. Moreover, they found no relationship between tree diversity and biomass, indicating that protected areas with high tree biomass for the compensation of greenhouse gas emissions will not necessary hold a great diversity of trees, highlighting difficult trade-offs between the conservation of biodiversity and the reduction of greenhouse gases in the sites. Fernandes et al. $\left(2018^{1}\right)$ show that rupestrian grasslands have one of the highest levels of plant endemism in the world but have also experienced some of the highest rates of habitat conversion due to mining activities, tourism, and infrastructure development. By forecasting its distribution under different climatic scenarios, they predict a catastrophic loss of $82 \%$ of their range, impacting ecosystem services, including water and food security in some of the most populous regions of Brazil.

Knowledge of Cerrado biodiversity has increased exponentially during the last two decades (Fig. 1). Notably, there have been significant advances in assessing spatial patterns of genetic diversity, the primary ingredient for evolution (e.g., Fenker et al. in press). Intraspecific genetic diversity plays a crucial role in species survival and adaptation, especially in the face of human-induced climate change and habitat loss (Laikre et al. 2020). Ballesteros-Mejia et al. (2020) assessed patterns of plant genetic variation across the Cerrado, emphasizing areas of high diversity and priority areas for conservation, and also determining the role of environmental characteristics and human impacts on genetic variation. They show that genetic richness decreases from north to south, being lower in regions

1 This contribution was published in advance of the completion of the Special Issue. 
with a high human development index, most likely atributable to habitat loss and fragmentation, and that variables related to energy, temperature, and precipitation are associated with genetic and allelic richness-but not with genetic diversity. They stress the importance of genetic studies in the northern Cerrado and within protected areas to enable better assessments of species conservation status and population management. Diniz-Filho et al. (2020) used the genetic diversity of a Cerrado tree to define conservation priorities based on predicted range shifts induced by climate change and habitat loss. They found a higher projected environmental suitability but a reduced proportion of natural habitats in southern Cerrado. Thus, in situ conservation seems adequate in the northern range of the species, where numerous natural remnants should hold more genetic diversity despite the reduced climatic suitability. In contrast, ex situ strategies should prove better in the southern part of the range, given the high levels of human occupation and despite the higher climatic stability. Different prioritization strategies for stable and unstable regions in the future should result an efficient conservation programme for the species.

Within the highly diverse Cerrado flora, several species are essential for the welfare of rural communities or are close relatives of cultivated species, being potentially useful for crop improvement. Sá et al. (2020) assessed the effects of land use and management upon the demography of an intensively used fruit palm endemic to the Cerrado. They show that, despite pressures from fruit harvesting and cattle ranching, most populations had good recruitment, but regeneration was meager under more intense land use and management. Therefore, populations in industrial farms under intense land use may be doomed, while those in small properties managed by traditional peoples and family farmers should persist. Supporting traditional peoples and family farmers effectively contributes to the in situ conservation of Cerrado's biodiversity in multiple-use landscapes. Simon et al. (2020) assessed the species conservation status of Cerrado wild relatives of cassava. They found many endemic species of cassava in the Cerrado, several of which are threatened with extinction owing to narrow geographic ranges and habitat loss. A substantial number of species was described recently, indicating that the diversity of cassava in the Cerrado has been very much underestimated. Species richness and endemism are highest in the Cerrado highlands, and more than half of the endemics are not represented in protected areas. More protected areas are therefore needed, particularly in areas with a concentration of rare and endemic species, to ensure effective in situ conservation of these crop wild relatives.

Human-induced habitat loss and climate change are rapidly increasing the extinction risk of Cerrado endemic species. Soon, ex situ breeding programmes may become commonplace for recovering populations that are threatened with extinction or already extinct in the wild. Machado et al. (2020) use a threatened songbird to examine scenarios that could produce viable populations in nature and to determine where reintroductions should take place. Their results suggest that reintroductions of a small number of individuals in several areas, with annual supplementation of a few individuals, could lead to long-term success. Nevertheless, few regions were found to be appropriate for reintroductions, including palm swamps (veredas) in central Cerrado. Further, they indicate that connecting habitat fragments, along with habitat matrix and fire management, are needed in places where reintroductions could be carried out.

A nefarious combination of rapid agribusiness and infrastructure development, illdesigned and poorly enforced environmental laws, alongside few incentives for research and conservation are engendering a major biodiversity collapse in the Cerrado (Alves et al. 2018; Fernandes et al. 2017; Overbeck et al. 2018; Strassburg et al. 2017). De Marco et al. (2020) assessed species and landscape vulnerability for threatened species of Cerrado mammals. They demonstrate that agriculture and transport infrastructure are the primary 
drivers of habitat loss and that highly preserved landscapes are mostly found in the northern Cerrado. At the same time, climatically suitable areas for threatened mammals coincide with profoundly impacted landscapes in the southern Cerrado. Their results underscore the necessity of conservation programmes focused on the survival of populations from highly impacted landscapes. Human-induced environmental impacts also translate into increased frequency and severity of fires in the Cerrado. Costa et al. (2020) assessed the effects of fire-induced microclimatic shifts upon Cerrado lizard communities. They found that fire suppression enhanced habitat structural complexity, whereas burning had the opposite effects; half of the lizard species were favoured in the fire-protected plot, while the other half was favoured in burned plots. Lizard body condition and survival rates were not affected by fire regimes, suggesting a dominant role of thermoregulation opportunities afforded by habitat structure-instead of food availability or predation rates-upon community structure. Their findings indicate that even sporadic fires can profoundly affect Cerrado lizard communities and that protecting some habitat patches from burning is essential to maximize the maintenance of lizard diversity.

The Cerrado harbours a rich and endemic biota that is hugely important to the economy in Brazil. Is it feasible to attain a balance between economic development and biodiversity conservation? Lemes et al. (2020) used areas suitable for agriculture to identify priority places to implement monocultures and modeled species distributions, avoiding sites with high conservation value, and used species dispersal abilities to minimize the distance between present-day and future suitable areas for species persistence. They found habitat conversion threatened species persistence and that unrestricted agricultural expansion into future species distributions is possible due to severe decreases in suitable areas for many species. Ecological knowledge should guide agriculture expansion to spare future areas suitable for Cerrado' species. Monteiro et al. (2020) identify spatial conservation priorities that minimize the risk of land conversion while retaining sites with high value for threatened plants at risk from climate change in the Cerrado. They show that scenarios that maximize conservation impact reduced total vegetation loss, while still covering large proportions of species ranges inside protected areas and priority sites. Hence, vegetation information could represent a reliable surrogate for overall biodiversity, allowing for the achievement of species representation and conservation impact.

Acknowledgements GRC thanks Coordenação de Aperfeiçoamento de Pessoal de Nível Superior (CAPES-Brazil), Conselho Nacional do Desenvolvimento Científico e Tecnológico (CNPq-Brazil), Fundação de Apoio à Pesquisa do Distrito Federal (FAPDF), and the USAID's PEER program under cooperative agreement AID-OAA-A-11-00012 for financial support.

\section{References}

Aguiar AJC, Melo GAR, Vasconcelos TNC, Goncalves RB, Giugliano L, Martins AC (2020) Biogeography and early diversification of Tapinotaspidini oil-bees support presence of Paleocene savannas in South America. Mol Phylogenet Evol 143:10. https://doi.org/10.1016/j.ympev.2019.106692

Albert JS, Reis RE (2011) Introduction to neotropical freshwaters. In: Albert JS, Reis RE (eds) Historical biogeography of neotropical freshwater fishes. University of California Press, Berkeley and Los Angeles, pp 3-19

Alvares CA, Stape JL, Sentelhas PC, Goncalves JLD, Sparovek G (2013) Köppen's climate classification map for Brazil. Meteorol Z 22:711-728. https://doi.org/10.1127/0941-2948/2013/0507

Alves RJV, Weksler M, Oliveira JA, Buckup PA, Pombal JP, Santana HRG, Peracchi AL, Kellner AWA, Aleixo A, Bonino ARL, De Almeida AMP, Albernaz AL, Ribas CC, Zilberberg C, Grelle CEV, Da Rocha CFD, Lamas CJE, Haddad CFB, Bonvicino CR, Prado CPA, De Lima DO, Rossa-Feres 
DC, Dos Santos FR, Salimena FRG, Perini FA, Bockmann FA, Franco FL, Del Giudice GML, Colli GR, Vieira ICG, Marinho J, Werneck J, Dos Santos JAD, Do Nascimento JL, Nessimian JL, Cordeiro JLP, Del Claro K, Salles LO, Casatti L, Py-Danie LHR, Silveira LF, Toledo LF, De Oliveira LF, Malabarba LR, Da Silva MD, Couri MS, Martins MRC, Tavares MDS, Sobral MEG, Vieira MV, Oliveira MDA, De Pinna MCC, Hopkins MJG, Sole M, Menezes NA, Passos P, D'Andrea PS, Pinto P, Viana PL, Toledo PM, Dos Reis RE, Vilela R, Bastos RP, Collevatti RG, Silva RC, Fisher SC, Caramaschi U (2018) Brazilian legislation on genetic heritage harms biodiversity convention goals and threatens basic biology research and education. An Acad Bras Cienc 90:1279-1284. https://doi. org/10.1590/0001-3765201820180460

Ballesteros-Mejia L, Lima JS, Collevatti RG (2020) Spatially-explicit analyses reveal the distribution of genetic diversity and plant conservation status in Cerrado biome. Biodivers Conserv. https://doi. org/10.1007/s10531-018-1588-9

Barbosa RI, Campos C, Pinto F, Fearnside PM (2007) The "Lavrados" of Roraima: biodiversity and conservation of Brazil's Amazonian Savannas. Functional Ecosystems and Communities 1:29-41

Beuchle R, Grecchi RC, Shimabukuro YE, Seliger R, Eva HD, Sano E, Achard F (2015) Land cover changes in the Brazilian Cerrado and Caatinga biomes from 1990 to 2010 based on a systematic remote sensing sampling approach. Appl Geogr 58:116-127. https://doi.org/10.1016/j.apgeog.2015.01.017

Borges SH (2008) A importância do ensino de pós-graduação na formação de recursos humanos para o estudo da biodiversidade no Brasil: Um estudo de caso na ornitologia. Biota Neotrop 8:21-27. https:// doi.org/10.1590/s1676-06032008000100002

Bortolozzi F, Gremski W (2004) Pesquisa e pós-graduação brasileira—assimetrias. Revista Brasileira de Pós-Graduação 1:35-52

Braun OPG (1970) Contribuição à geomorfologia do Brasil central. Revista Brasileira de Geografia 32:3-39

Carneiro Filho A (1993) Cerrados amazônicos: fósseis vivos? Algumas reflexões. Revista IG, São Paulo $14: 63-68$

Cole MM (1960) Cerrado, Caatinga and Pantanal: the distribution and origin of the savanna vegetation of Brazil. Geogr J 126:168-170. https://doi.org/10.2307/1793957

Colli GR (2005) As origens e a diversificação da herpetofauna do Cerrado. In: Scariot A, Souza-Silva JC, Felfili JM (eds) Cerrado: Ecologia. Biodiversidade e Conservação Ministério do Meio Ambiente, Brasília-DF, pp 247-264

Colli GR, Bastos RP, Araújo AFB (2002) The character and dynamics of the Cerrado herpetofauna. In: Oliveira PS, Marquis RJ (eds) The Cerrados of Brazil: ecology and natural history of a neotropical Savanna. Columbia University Press, New York, NY, pp 223-241

Colli GR, Fenker J, Tedeschi LG, Barreto-Lima AF, Mott T, Ribeiro SLB (2016) In the depths of obscurity: Knowledge gaps and extinction risk of Brazilian worm lizards (Squamata, Amphisbaenidae). Biol Conserv 204:51-62. https://doi.org/10.1016/j.biocon.2016.07.033

Costa BM, Pantoja DL, Sousa HC, de Queiroz TA, Colli GR (2020) Long-term, fire-induced changes in habitat structure and microclimate affect Cerrado lizard communities. Biodivers Conserv:23. https:// doi.org/10.1007/s10531-019-01892-8

Costa BM, Pantoja DL, Vianna MCM, Colli GR (2013) Direct and short-term effects of fire on lizard assemblages from a Neotropical savanna hotspot. J Herpetol 47:502-510. https://doi.org/10.1670/12-043

De Marco P, Jr., Villén S, Mendes P, Nóbrega C, Cortes L, Castro T, Souza R, (2020) Vulnerability of Cerrado threatened mammals: An integrative landscape and climate modeling approach. Biodivers Conserv. https://doi.org/10.1007/s10531-018-1615-X

Diniz IR, Marinho-Filho J, Machado RB, Cavalcanti RB (2010) Cerrado: Conhecimento Científico Quantitativo como Subsídio para Ações de Conservação. Editora UnB, Brasília

Diniz-Filho JAF, Bastos RP, Rangel TFLVB, Bini LM, Carvalho P, Silva RJ (2005) Macroecological correlates and spatial patterns of anuran description dates in the Brazilian Cerrado. Glob Ecol Biogeogr 14:469-477. https://doi.org/10.1111/j.1466-822x.2005.00165.x

Diniz-Filho JAF, ACDOF Barbosa, Chaves LJ, e Souza KDS, Dobrovolski R, Rattis L, Terribile LC, LimaRibeiro MS, de Oliveira G, Brum FT, Loyola R, de Campos TMP, (2020) Overcoming the worst of both worlds: Integrating climate change and habitat loss into spatial conservation planning of genetic diversity in the Brazilian Cerrado. Biodivers Conserv. https://doi.org/10.1007/s10531-018-1667-y

Eiten G (1972) The Cerrado vegetation of Brazil. Bot Rev 38:201-341. https://doi.org/10.1007/BF02859158

Eiten G (1994) Vegetação do Cerrado. In: Pinto MN (ed) Cerrado: Caracterização, Ocupação e Perspectivas. Editora da Universidade de Brasília, Brasília, pp 17-73

Espírito-Santo MM, Leite ME, Silva JO, Barbosa RS, Rocha AM, Anaya FC, Dupin MGV (2016) Understanding patterns of land-cover change in the Brazilian Cerrado from 2000 to 2015. Philos T R Soc B 371:11. https://doi.org/10.1098/rstb.2015.0435 
Fenker J, Domingos FMCB, Tedeschi LG, Rosauer DF, Werneck FP, Colli GR, Ledo RMD, Fonseca EM, Garda AA, Tucker D, Sites JW, Jr., Breitman MF, Soares F, Giugliano LG, Moritz C (2020) Evolutionary history of Neotropical savannas geographically concentrates species, phylogenetic and functional diversity of lizards. J Biogeogr. https://doi.org/10.1111/jbi.13800

Fernandes GW, Barbosa NPU, Alberton B, Barbieri A, Dirzo R, Goulart F, Guerra TJ, Morellato LPC, Solar RRC (2018) The deadly route to collapse and the uncertain fate of Brazilian rupestrian grasslands. Biodivers Conserv 27:2587-2603. https://doi.org/10.1007/s10531-018-1556-4

Fernandes GW, Vale MM, Overbeck GE, Bustamante MMC, Grelle CEV, Bergallo HG, Magnusson WE, Akama A, Alves SS, Amorim A, Araujo J, Barros CF, Bravo F, Veiga Carim MJ, Cerqueira R, Collevatti RG, Colli GR, da Cunha CN, D’Andrea PS, Dianese JC, Diniz S, Estrela PC, Fernandes MRM, Fontana CS, Giacomin LL, Gusmao LFP, Junca FA, Borges Lins-e-Silva AC, Lopes CRAS, Lorini ML, de Queiroz LP, Malabarba LR, Marimon BS, Marimon Junior BH, Marques MCM, Martinelli BM, Martins MB, de Medeiros HF, Menin M, de Morais PB, Muniz FH, Neckel-Oliveira S, de Oliveira JA, Oliveira RP, Pedroni F, Penha J, Podgaiski LR, Rodrigues DJ, Scariot A, Silveira LF, Silveira M, Tomas WM, Salgado Vital MJ, Pillar VD (2017) Dismantling Brazil's science threatens global biodiversity heritage. Perspect Ecol Conserv 15:239-243. https://doi.org/10.1016/j.pecon.2017.07.004

Françoso RD, Brandão R, Nogueira CC, Salmona YB, Machado RB, Colli GR (2015) Habitat loss and the effectiveness of protected areas in the Cerrado Biodiversity Hotspot. Nat Conserv 13:35-40. https:// doi.org/10.1016/j.ncon.2015.04.001

Françoso RD, Dexter KG, Machado RB, Pennington RT, Pinto JRR, Brandão RA, Ratter JA (2020) Delimiting floristic biogeographic districts in the Cerrado and assessing their conservation status. Biodivers Conserv. https://doi.org/10.1007/s10531-019-01819-3

Frost PGH (1985) The responses of savanna organisms to fire. In: Tothill JC, Mott JJ (eds) Ecology and management of the World's Savannas. Australian Academy of Science, pp 232-237

Fundação Biodiversitas (2003) Lista da Fauna Brasileira Ameaçada de Extinção. Fundação Biodiversitas, Belo Horizonte, Brasil

Furley PA (1999) The nature and diversity of Neotropical savanna vegetation with particular reference to the Brazilian cerrados. Glob Ecol Biogeogr 8:223-241. https://doi.org/10.1046/J.1466-822x.1999.00142 X

Grecchi RC, Gwyn QHJ, Benie GB, Formaggio AR, Fahl FC (2014) Land use and land cover changes in the Brazilian Cerrado: A multidisciplinary approach to assess the impacts of agricultural expansion. Appl Geogr 55:300-312. https://doi.org/10.1016/j.apgeog.2014.09.014

Green PJ, Silverman BW (1994) Nonparametric Regression and Generalized Linear Models: A roughness penalty approach. Chapman \& Hall, London

Hoffmann WA (2002) Direct and indirect effects of fire on radial growth of cerrado savanna trees. J Trop Ecol 18:137-142. https://doi.org/10.1017/S0266467402002080

Hoffmann WA, Jackson RB (2000) Vegetation-climate feedbacks in the conversion of tropical savanna to grassland. J Climate 13:1593-1602. https://doi.org/10.1175/1520-0442(2000)013\%3c1593:VCFIT $\mathrm{C} \% 3 \mathrm{e} 2.0 . \mathrm{CO} ; 2$

IUCN (2013) IUCN red list of threatened species. Version 2013.2. www.iucnredlist.org. Accessed 06 April 2014

King LC (1956) A geomorfologia do Brasil Oriental. Revista Brasileira de Geografia 18:147-265

Laikre L, Hoban S, Bruford MW, Segelbacher G, Allendorf FW, Gajardo G, Rodríguez AG, Hedrick PW, Heuertz M, Hohenlohe PA, Jaffé R, Johannesson K, Liggins L, MacDonald AJ, OrozcoterWengel P, Reusch TBH, Rodríguez-Correa H, Russo I-RM, Ryman N, Vernesi C (2020) Post-2020 goals overlook genetic diversity. Science 367:1083-1085. https://doi.org/10.1126/science.abb2748

Lemes L, de Andrade AFA, Loyola R (2020) Spatial priorities for agricultural development in the Brazilian Cerrado: May economy and conservation coexist? Biodivers Conserv. https://doi.org/10.1007/s1053 1-019-01719-6

Lopes AS, Cox FR (1977) Survey of fertility status of surface soils under Cerrado vegetation in Brazil. Soil Sci Soc Am J 41:742-747. https://doi.org/10.2136/sssaj1977.03615995004100040026x

Machado RB, Neto MBR, Pereira PGP, Caldas EF, Gonçalves DA, Santos NS, Tabor K, Steininger M (2004) Estimativas de perda da área do Cerrado brasileiro. Conservação Internacional, Brasília, DF

Machado RB, Silveira LF, da Silva MISG, Ubaid FK, Medolago CA, Francisco MR, Dianese JC (2020) Reintroduction of songbirds from captivity: the case of the Great-billed Seed-finch (Sporophila maximiliani) in Brazil. Biodivers Conserv. https://doi.org/10.1007/s10531-019-01830-8

Mantovani JE, Pereira LA (1998) Estimativa da integridade da cobertura vegetal do Cerrado/Pantanal através de dados TM/Landstat. Relatório apresentado no Workshop "Ações Prioritárias para a Conservação do Cerrado e Pantanal”. Funatura, Conservation International, Universidade de Brasília, Fundação Biodiversitas, Brasília, Brasil 
Marques EQ, Marimon-Junior BH, Marimon BS, Matricardi EAT, Mews HA, Colli GR (2020) Redefining the Cerrado-Amazonia transition: Implications for conservation. Biodivers Conserv. https://doi. org/10.1007/s10531-019-01720-z

Marris E (2005) The forgotten ecosystem. Nature 437:944-945. https://doi.org/10.1038/437944a

Miranda HS, Sato MN, Nascimento WN, Aires FS (2009) Fires in the Cerrado, the Brazilian savanna. In: Cochrane MA (ed) Tropical fire ecology: climate change, land use, and ecosystem dynamics. Springer and Praxis Publishing Ltd, Chichester, UK, pp 427-450

Mistry J (1998) Fire in the Cerrado (savannas) of Brazil: an ecological review. Prog Phys Geogr 22:425448. https://doi.org/10.1177/030913339802200401

Mittermeier RA, Myers N, Gill PC, Mittermeier CG (2000) Hotspots: Earth's Richest and most endangered terrestrial ecoregions. CEMEX, Mexico City

Monteiro LM, Brum FT, Pressey RL, Morellato LPC, Soares-Filho B, Lima-Ribeiro MS, Loyola R (2020) Evaluating the impact of future actions in minimizing vegetation loss from land conversion in the Brazilian Cerrado under climate change. Biodivers Conserv. https://doi.org/10.1007/s1053 1-018-1627-6

Morandi PS, Marimon BS, Marimon-Junior BH, Ratter JA, Feldpausch TR, Colli GR, Munhoz CBR, da Silva Júnior MC, de Souza LE, Haidar RF, Arroyo L, Murakami AA, de Góis AF, Walter BMT, Ribeiro JF, Françoso R, Elias F, de Oliveira EA, Reis SM, de Oliveira B, das Neves EC, Nogueira DS, Lima HS, de Carvalho TP, Rodrigues SA, Villarroel D, Felfili JM, Phillips OL, (2020) Tree diversity and above-ground biomass in the South America Cerrado biome and their conservation implications. Biodivers Conserv. https://doi.org/10.1007/s10531-018-1589-8

Motta PEF, Curi N, Franzmeier DP (2002) Relation of soils and geomorphic surfaces in the Brazilian Cerrado. In: Oliveira PS, Marquis RJ (eds) The Cerrados of Brazil. Columbia University Press, New York, Ecology and natural history of a neotropical Savanna, pp 13-32

Myers N (2003) Biodiversity hotspots revisited. Bioscience 53:916-917. https://doi. org/10.1641/0006-3568(2003)053[0916:BHR]2.0.CO;2

Myers N, Mittermeier RA, Mittermeier CG, da Fonseca GAB, Kent J (2000) Biodiversity hotspots for conservation priorities. Nature 403:853-858. https://doi.org/10.1038/35002501

Nimer E (1989) Climatologia do Brasil. IBGE, Departamento de Recursos Naturais e Estudos Ambientais, Rio de Janeiro

Nogueira C, Valdujo PH, Franca FGR (2005) Habitat variation and lizard diversity in a Cerrado area of central Brazil. Stud Neotrop Fauna Environ 40:105-112. https://doi.org/10.1080/016505205001299 01

Oliveira PS, Marquis RJ (2002) The Cerrados of Brazil. Columbia University Press, New York, Ecology and natural history of a neotropical Savanna

Oliveira-Filho AT, Ratter JA (2002) Vegetation physiognomies and woody flora of the Cerrado biome. In: Oliveira PS, Marquis RJ (eds) The Cerrados of Brazil. Columbia University Press, New York, Ecology and natural history of a neotropical Savanna, pp 91-120

Overbeck GE, Bergallo HG, Grelle CEV, Akama A, Bravo F, Colli GR, Magnusson WE, Tomas WM, Fernandes GW (2018) Global biodiversity threatened by science budget cuts in Brazil. Bioscience 68:11-12. https://doi.org/10.1093/biosci/bix130

Pennington RT, Prado DE, Pendry CA (2000) Neotropical seasonally dry forests and Quaternary vegetation changes. J Biogeogr 27:261-273. https://doi.org/10.1046/j.1365-2699.2000.00397.x

Rambaldi DM, Oliveira DAS (2003) Fragmentação de Ecossistemas: Causas. Efeitos sobre a Biodiversidade e Recomendações de Políticas Públicas, Ministério do Meio Ambiente/Secretaria de Biodiversidade e Florestas, Brasília

Ratter JA, Ribeiro JF, Bridgewater S (1997) The Brazilian Cerrado vegetation and threats to its biodiversity. Ann Bot 80:223-230. https://doi.org/10.1006/anbo.1997.0469

Ribeiro JF, Walter BMT (1998) Fitofisionomias do bioma Cerrado. In: Sano SM, Almeida SP (eds) Cerrado: Ambiente e Flora. EMBRAPA, Planaltina, pp 89-166

Romero EJ (1993) South American paleofloras. In: Goldblatt P (ed) Biological Relationships between Africa and South America. Yale University Press, New Haven and London, pp 62-85

Sá D, Scariot A, Ferreira JB (2020) Effects of ecological and anthropogenic factors on population demography of the harvested Butia capitata palm in the Brazilian Cerrado. Biodivers Conserv. https://doi.org/10.1007/s10531-018-1669-9

Salgado-Labouriau ML, Ferraz-Vicentini KR (1994) Fire in the Cerrado 32,000 years ago. Curr Res Pleistocene 11:85-87

Sano EE, Rosa R, Brito JLS, Ferreira LG (2010) Land cover mapping of the tropical savanna region in Brazil. Environ Monit Assess 166:113-124. https://doi.org/10.1007/S10661-009-0988-4 
Sano EE, Rodrigues AA, Martins ES, Bettiol GM, Bustamante MMC, Bezerra AS, Couto AF, Vasconcelos V, Schuler J, Bolf EL (2019) Cerrado ecoregions: a spatial framework to assess and prioritize Brazilian savanna environmental diversity for conservation. J Environ Manage 232:818-828. https ://doi.org/10.1016/j.jenvman.2018.11.108

Santos TCC, Câmara JBD (2002) GEO Brazil 2002-Environmental Outlooks in Brazil. IBAMA Editions, Brasília

Schmidt KP, Inger RF (1951) Amphibians and reptiles of the Hopkins- Branner Expedition to Brazil. Fieldiana Zool 31:439-465. https://doi.org/10.5962/bhl.title.3198

Simon MF, Grether R, de Queiroz LP, Skema C, Pennington RT, Hughes CE (2009) Recent assembly of the Cerrado, a Neotropical plant diversity hotspot, by in situ evolution of adaptations to fire. Proc Natl Acad Sci USA 106:20359-20364. https://doi.org/10.1073/pnas.0903410106

Simon MF, Reis TS, Mendoza FJM, Arquelão TKM, Bringel JBA, Noronha SE, Martins MLL, Ledo CAS, Silva MJ, Sampaio AB, Matricardi ET, Scariot A (2020) Conservation assessment of cassava wild relatives in central Brazil. Biodivers Conserv. https://doi.org/10.1007/s10531-018-1626-7

Strassburg BBN, Brooks T, Feltran-Barbieri R, Iribarrem A, Crouzeilles R, Loyola R, Latawiec AE, Oliveira FJB, Scaramuzza CAD, Scarano FR, Soares B, Balmford A (2017) Moment of truth for the Cerrado hotspot. Nat Ecol Evol 1:3. https://doi.org/10.1038/s41559-017-0099

Vanzolini PE (1963) Problemas faunísticos do Cerrado. In: Ferri MG (ed) Simpósio Sobre o Cerrado. Editora da Universidade de São Paulo, São Paulo, pp 307-320

Vendrame PRS, Brito OR, Martins ES, Quantin C, Guimaraes MF, Becquer T (2013) Acidity control in latosols under long-term pastures in the Cerrado region, Brazil. Soil Res 51:253-261. https://doi. org/10.1071/sr12214

Werneck FP (2011) The diversification of eastern South American open vegetation biomes: historical biogeography and perspectives. Quat Sci Rev 30:1630-1648. https://doi.org/10.1016/j.quasc irev.2011.03.009

Publisher's Note Springer Nature remains neutral with regard to jurisdictional claims in published maps and institutional affiliations. 